\title{
Influências de metodologias de aula nos discursos sobre aula de Física de estudantes do Ensino Médio ${ }^{+*}$
}

Dayvid Bruno Fernandes da Silva ${ }^{1}$

Mestrando do Programa de Pós-Graduação Multiunidades em

Ensino de Ciências - Universidade Estadual de Campinas

Fernanda Cátia Bozelli ${ }^{1}$

Faculdade de Engenharia - Universidade Estadual Paulista

Ilha Solteira - SP

\section{Resumo}

Com o objetivo de investigar os discursos sobre aula de Física de alunos do Ensino Médio de uma escola estadual paulista, foram organizados grupos focais com alunos voluntários de primeira e de terceira séries daquela mesma escola. O registro de dados ocorreu por meio de gravações de áudio que foram transcritas para a análise guiada por noções da teoria de Análise de Discurso francesa apresentada por Orlandi. A interpretação dos dados propiciou diferentes olhares sobre os discursos a respeito das aulas de Física dos estudantes que participaram da pesquisa e sua relação com a metodologia de aula. A análise apontou discursos que suscitam sentidos de aulas de Física que se filiam a metodologias que priorizam o acúmulo e a memorização de conteúdo, equações e exercícios quantitativos. São aulas nas quais não há o estímulo ao questionamento e a Física é entendida como uma verdade irrefutável. Nessas condições, o agente principal das aulas é o professor e as subjetividades dos alunos são desprestigiadas, bem como o caráter social, histórico, político e cultural da própria Física. Por outro lado, evidenciam-se discursos de alunos que vivenciam aulas de Física nas quais os professores empregam metodologias que propiciam uma participação mais ativa dos alunos fazendo com que demonstrem maior interesse por essa disciplina.

\footnotetext{
${ }^{+}$Influences of class methodology on discourses about Physics class of high school students

* Recebido: setembro de 2018.

Aceito: agosto de 2019.

${ }^{1}$ E-mails: f_dayvid@yahoo.com; fernandaboz@gmail.com
} 
Palavras-chave: Ensino de Física; Ensino Médio; Metodologias de Aula; Análise de Discurso.

\begin{abstract}
In order to investigate the discourses about Physics class of high school students from a state school in São Paulo, focus groups were organized with first and third grade volunteer students from that same school. Data were recorded using audio recordings which were transcribed for analysis guided by notions of Orlandi's theory of French Discourse Analysis. The comprehension of the data provided different perspectives on the discourses about the Physics classes of the students who participated in the research and its relationships with the classroom methodologies. The analysis indicated discourses that raise the meaning of Physics classes that are affiliated with methodologies that prioritize the accumulation and memorization of content, equations and quantitative exercises. These are classes in which there is no stimulus to questions and debates; thus Physics is understood as an irrefutable scientific truth. Under these conditions, the main agent of the classes is the teacher and the subjectivities of the students are discredited, as well as the social, historical, political and cultural qualities of Physics itself. On the other hand, there are discourses of students who experienced Physics classes in which teachers employed methodologies that provide a more active participation of students, making them show greater interest in this subject.
\end{abstract}

Keywords: Discourse; Physics Class; High School; Class Methodologies; Students.

\title{
I. Introdução
}

Se tivéssemos que descrever como é uma aula de Física no Ensino Médio do Brasil, atualmente, como ela seria? O que seria diferente das aulas de décadas atrás? Estaríamos falando do uso de metodologias e recursos inovadores, de valorização da Ciência? Moreira (2018) ao discutir o ensino de Física ressalta enfaticamente que este "está em crise". Ou seja, destaca que somos produtores de pesquisas reconhecidas internacionalmente e de recursos e materiais instrucionais, mas tudo isso tem tido pouco ou nenhum reflexo no ensino de Física.

A carga horária semanal que chegou a 6 horas-aula por semana, hoje é de 2 ou menos. Aulas de laboratório praticamente não existem. Faltam professores de Físi- 
ca nas escolas e os que existem são obrigados a treinar os alunos para as provas, para as respostas corretas, ao invés de ensinar Física. A interdisciplinaridade e a transdisciplinaridade são confundidas com não disciplinaridade e tiram a identidade da Física. Os conteúdos curriculares não vão além da Mecânica Clássica e são abordados da maneira mais tradicional possível, totalmente centrada no professor, baseada no modelo de narrativa criticado por Finkel (1999), na educação bancária de Freire (2007), no comportamentalismo de Skinner (1972) (MOREIRA, 2018, p. 73).

Para Bonadiman e Nonenmacher (2007) os modelos tradicionais de ensino de Física estão intimamente ligados a insucessos no ensino básico (e no superior). Citam que esse fato pode ser percebido na "evasão escolar, no alto índice de repetência, na crescente difusão dos chamados cursinhos informais preparatórios e, principalmente, no fraco desempenho dos alunos [...]” (p. 195), além de resultados de avaliações externas, como o Programa Internacional de Avaliação de Alunos (PISA), o Exame Nacional do Ensino Médio (ENEM) e o Exame Nacional de Desempenho dos Estudantes (ENADE).

Não se objetiva o escamoteamento da utilização de equações físicas e exercícios numéricos. O que se defende é uma variedade metodológica que evite a cristalização de modelos pedagógicos arcaicos (RICARDO; FREIRE, 2007; SILVA et al. 2018; LABURÚ; ARRUDA; NARDI, 2003), que geralmente se baseiam em o professor transmitir conteúdos para que os estudantes, de forma passiva, os memorizem para provas e outros tipos de avaliações. Nesse contexto, Ricardo e Freire (2007) indicam que a minoria dos alunos consegue perceber alguma diferença entre Física e Matemática. Freire (2007) indica que:

Uma quantidade expressiva de alunos que estão prestes a concluir a última etapa
do ensino básico acha que a Física e a Matemática são a mesma coisa, ou quase
iguais, [...] eles deixarão o ambiente escolar achando que a Física é só a Matemáti-
ca aplicada (p. 10).

Em tais tipos de aula, a aprendizagem de Física e os alunos enquanto cidadãos pensantes são prejudicados (LABURÚ; ARRUDA; NARDI, 2003; BONADIMAN; NONENMACHER, 2007). Isso é posto pois sentidos equivocados sobre aula de Física são construídos e enraizados entre os estudantes que, após o último estágio de sua formação básica, provavelmente não retornarão a ter um contato formal com a Física, além de terem desenvolvido uma apatia pela Ciência devido aos próprios modelos de ensino (BONADIMAN; NONENMACHER, 2007).

Cunha (1995), Laburú, Arruda e Nardi (2003) concordam que a escola é um ambiente intrincado por diversas influências (históricas, políticas, econômicas, sociais, culturais, etc.) e está em constante transformação. Os professores também possuem um histórico pessoal, muitas vezes mais forte que sua formação inicial, que influencia suas escolhas metodológicas (CUNHA, 1995). Também pensando nas subjetividades dos alunos, bem como suas diferentes preferências por modelos de aulas, Laburú, Arruda e Nardi (2003) defendem a pluralidade 
metodológica na prática pedagógica de forma análoga ao pluralismo epistemológico de Feyerabend (1977). Os autores elucidam que todos os modelos pedagógicos possuem vantagens e desvantagens, bem como limitações. Ainda, considerando o caráter mutável da escola, explicam que nenhuma postura pedagógica deve ser eterna e inflexível. Isto posto, a diversidade metodológica ${ }^{2}$ mostra-se mais eficiente, além de poder privilegiar particularidades de professores, de estudantes.

No que se refere à estagnação metodológica, Lemke (1990) tece críticas em relação às aulas de Ciências que não possibilitam que os estudantes realmente discutam e se apropriem dos conhecimentos científicos. Recomenda que, para superar esses tipos de modelos de aula, seja proporcionada uma variedade maior de atividades nas quais os estudantes possam dialogar, perguntar, argumentar e discutir, não apenas com o professor, mas também entre si. Nesse entendimento, a diversidade metodológica pode contemplar um maior número de aprendizes e possibilitar articulações com os conceitos físicos por diferentes vias.

Já para Libâneo (2002), além da apropriação de conteúdos científicos, deve haver apropriação da cultura. Seu argumento visa o desenvolvimento de diferentes aprendizagens dos alunos, ou seja, "o ensino, portanto, propicia a apropriação da cultura e da ciência, e o desenvolvimento do pensamento, por meio da formação e operação com conceitos” (p. 10). Para isso, a interdisciplinaridade também é defendida, sendo aconselhado, inclusive, o uso de diferentes textos:

A diversidade de textos concorre para o reconhecimento dos gêneros como expressões históricas e culturais diversificadas, que vão se modificando ao longo do tempo. Hoje, mais do que nunca, as transformações tecnológicas podem atropelar o trabalho de uma escola que se cristaliza em "modelos" estanques. Nesse sentido, os gêneros devem receber o enfoque específico de cada disciplina e, ao mesmo tempo, precisam ser trabalhados de modo interdisciplinar (SÃO PAULO, 2012, p. 15).

E, ainda, "ensina-se física, no ensino médio, para preparar o aluno para lidar com situações reais de crises de energia, problemas ambientais, manuais de aparelhos, concepção de universo, exames médicos, notícias de jornal e assim por diante" (BRASIL, 2002, p. 61).

Nessa perspectiva, é importante articular a disciplina de Física de maneira interdisciplinar a fim de vencer velhos padrões de ensino, aproveitando a contribuição do uso de diferentes tipos de textos para o aprimoramento da leitura e escrita. Apresentar conceitos físicos de forma isolada, como irrefutáveis e universais, é destituir a Física de suas relações com a história, com a política e com o próprio fazer científico (DAMASIO; RODRIGUES, 2018).

Defende-se que a escola é local de desenvolvimento de uma formação para a cidadania (CARVALHO JÚNIOR, 2002; DAMASIO; RODRIGUES, 2018). Ou seja, as aprendizagens vão além das resoluções repetitivas de exercícios e se estabelecem em uma proposta que

\footnotetext{
${ }^{2}$ Importante salientar que o que está se chamando aqui de "metodologias de aula" refere-se às estratégias utilizadas pelos professores para ensinar Física.
} 
integra elementos culturais e sociais. Nessa linha de raciocínio, Lemke (1990) também sugere que o teor social esteja aliado às aulas de disciplinas científicas. $\mathrm{O}$ autor lança mão do termo falar Ciência como habilidade a ser desenvolvida para que os alunos possam, de fato, aprender Ciências. A aprendizagem de Física se daria em diferentes vias: falar, ler e escrever sobre os conceitos científicos em diferentes contextos, relacionando os conceitos entre si. Nesse sentido, o ensino de Física abrange seu corpo de conhecimentos, seus processos de construção de conhecimento e as relações históricas, filosóficas e culturais relacionadas à prática científica (BALLESTERO; ARRUDA; PASSOS, 2018; DAMASIO; RODRIGUES, 2018).

Nessa linha de raciocínio é compreendido que é possível se valer de diferentes metodologias e materiais didáticos para que possa haver uma abordagem holística no ensino, uma vez que,

o desenvolvimento de códigos e linguagens em ciência e tecnologia deve ser tomado como um aspecto formativo de interesse amplo, ou seja, no ensino de cada disciplina científica, esse desenvolvimento não está somente a serviço dessa determinada ciência ou das ciências, mas sim promovendo uma competência geral de representação e comunicação (BRASIL, 2002, p. 24).

Dessa forma, é razoável dizer que é possível desfrutar de outras áreas do conhecimento em aulas de Física evitando que a mesma seja tratada de forma isolada de outros conteúdos, do contexto global da sociedade e do próprio contexto social dos estudantes (SÃO PAULO, 2008; NARDI; CASTIBLANCO, 2014). Todavia, por diversos motivos, como desvalorização do trabalho docente, condições de trabalho precárias, concepções epistemológicas, falta de material didático e questões relacionadas à formação inicial e continuada de professores, as aulas de Física acabam sendo desprestigiadas (CUNHA, 1995; BONADIMAN; NONENMACHER, 2007; RICARDO; FREIRE, 2007).

Diante de tais considerações, a motivação da presente pesquisa teve início a partir de observações e regências de aulas de Física para o Ensino Médio realizadas em uma escola estadual pública do interior de São Paulo, no contexto da realização do estágio supervisionado do primeiro autor, então discente de um Curso de Licenciatura em Física. Naquele momento, foi percebido um modelo geralmente denominado tradicional, que coincide com o que é descrito por Laburú, Arruda e Nardi (2003): 'baseado na lógica da 'doação' do saber, que privilegia a audição em detrimento da fala" (p. 248) e que "advoga e prescreve o domínio de um ensino mecânico, ritualista, de observação, de audição, centrado tão somente no professor" (p. 251). São aulas nas quais o professor transcreve conteúdos na lousa, sem muita discussão conceitual, e os alunos, de suas posições passivas, os copiam e os memorizam para futura verificação em provas (LEMKE, 1990; LIBÂNEO, 2002; LABURÚ; ARRUDA; NARDI, 2003; RICARDO; FREIRE, 2007). Bonadiman e Nonenmacher (2007) entendem que este tipo de aula propicia a antipatia dos alunos pela Física, ao passo que Damasio e Rodrigues (2018) concordam que esse tipo metodologia é ineficiente para a aprendizagem científica. 
Naquela oportunidade, depois de observadas várias aulas de Física em algumas turmas do Ensino Médio, foi realizado o estágio de regência, no qual foi desenvolvida uma unidade de ensino proposta à uma turma de terceira série. A unidade de ensino contemplava a utilização de diferentes tipos de texto, como poemas, ficção científica, história em quadrinhos, entre outros, a respeito da temática energia elétrica. Dessa forma, poderia ser possível uma gama maior de aprendizagens (LABURÚ; ARRUDA; NARDI, 2003). No entanto, alguns alunos foram relutantes à proposta, pois, segundo eles, aquele "tipo de aula" que envolvia leituras, escritas e discussões, deveria estar inserido no contexto das aulas de Língua Portuguesa. Segundo os estudantes, em aulas de Física deveria haver a resolução de equações e exercícios. Diante do presente cenário foram levantados questionamentos sobre o imaginário dos estudantes no que se refere a aulas de Física. Entre outras reflexões, foi ponderado sobre a influência das metodologias de aula na concepção de aula de Física dos mesmos. Essa vivência oportunizou problematizar sobre a existência de sentidos diversos sobre aula de Física baseados nas condições de produção nas quais foram produzidos.

De acordo com Laburú, Arruda e Nardi (2003), "todo ensino, como atividade humana é intercultural, devido às múltiplas identidades microculturais de todos os estudantes e, por essa razão, os indivíduos reagem e são afetados diferentemente pelas ações dos professores" (p. 252). Ainda,

se uma palavra, expressão, proposição podem receber sentidos diferentes [...] elas não têm um sentido que lhes seria "próprio" enquanto ligado à sua literalidade, mas seu sentido se constitui em cada formação discursiva, nas relações que entretêm com outras palavras, expressões proposições da mesma formação discursiva (PÊCHEUX, 1975 apud BRANDÃO, 2002, p. 145).

Já que a língua não é transparente e a formação de sentidos é múltipla, esta pesquisa procurou investigar: Como se dá a formação de sentidos de aula de Física suscitados nos discursos de alunos do Ensino Médio de uma escola estadual paulista? O processo de compreensão dos discursos foi balizado pela teoria francesa de Análise de Discurso (AD), segundo Pêcheux e divulgada no Brasil, entre outros, por Eni Orlandi. A partir da análise foram realizadas diferentes relações com aspectos de aula de Física, tais como: a formação inicial de docentes, a influência de estagiários, a metodologia de aula, aspectos do sistema educacional, entre outras. É sabido que são diversos os elementos que influenciam as aulas, como "a pouca valorização do profissional do ensino, as precárias condições de trabalho do professor" (BONADIMAN, NONENMACHER, 2007, p. 196), contudo, aqui será apresentada a análise que teve foco no estudo do discurso dos estudantes sobre aula de Física e sua relação com as metodologias utilizadas pelos professores. 


\section{Aula de Física}

As escolhas metodológicas realizadas pelo professor de Física têm o potencial de afetar o imaginário dos estudantes sobre essa disciplina. Isso é dito pois, um mesmo conceito pode receber sentidos diferentes de acordo com suas condições de produção (BRANDÃO, 2002; ORLANDI, 2003, 2017), o que, no caso específico das aulas de Física, pode ser remetido às metodologias de aula (LABURÚ; ARRUDA; NARDI, 2003; BONADIMAN; NONENMACHER, 2007). Bonadiman e Nonenmacher (2007) entendem que a forma como a Física é ensinada tem o poder de estimular ou desestimular a aprendizagem e comentam que muitos alunos chegam do Ensino Fundamental com grande interesse e curiosidade pela Física, mas logo desanimam e apresentam baixos índices de aprendizagem. Um dos fatores que pode estar relacionado é o da prática docente. Zabala (1998) explica que é fundamental o papel de mediação, direção e supervisão pelo professor sugerindo que este propicie a atividade independente, autônoma e criativa dos estudantes. Ainda, que os movimentos de ensino e de aprendizagem envolvem diversas variáveis em uma teia complexa, tais como, "tipo de atividade metodológica, aspectos materiais da situação, estilo do professor, relações sociais, conteúdos culturais, etc.” (p. 15). Em vista disso, o professor tem o papel de refletir sobre os diferentes fatores que influenciam sua prática e planejar diferentes atividades no intento de incentivar os estudantes no desenvolvimento de suas capacidades e habilidades, podendo ser sujeitos ativos em sua própria aprendizagem.

Em um panorama oposto a este, críticas se direcionam a aulas pautadas na memorização de conceitos de forma que não forneçam o envolvimento ativo dos alunos. Para Lemke (1990), esse tipo de aula perpetua a crença em uma Ciência dogmática, autoritária, impessoal, mitificada e sobre-humana. Esse tipo de representação identifica os cientistas como seres dotados de superinteligência com os quais os alunos não se identificam.

Damásio e Rodrigues (2018) reforçam a ideia de que as funções de professor transmissor de conteúdos e alunos receptores não fazem mais sentido em um mundo em que as fontes de informação são múltiplas e acessíveis. Para Laburú, Arruda e Nardi (2003), no caso das aulas de Física, estas seriam aulas baseadas na metodologia da doação, nas quais o professor fala e os estudantes escutam e copiam. São aulas que, entre outros aspectos, se baseiam na resolução repetitiva de exercícios quantitativos em detrimento do pluralismo de metodologias e de recursos didáticos.

os estudantes variam em suas motivações e preferências, no que se refere ao estilo ou ao modo de aprender, e mesmo na sua relação com o conhecimento. Isso sem mencionar as suas habilidades mentais específicas, ritmos de aprendizagem, nível de motivação e interesse para uma determinada disciplina, persistência dedicada a um problema, experiências vividas pelo grupo social a que pertencem. Esses fatores que podem vir a ser colocados numa sala de aula, certamente influenciam, entre outros, a qualidade e a profundidade da aprendizagem, como, também, a decisão do emprego da estratégia metodológica. Portanto, é questionável uma ação educacio- 
nal baseada num único estilo didático, que só daria conta das necessidades de um tipo particular de aluno ou alunos e não de outros (LABURÚ, ARRUDA, NARDI, 2003, p. 251).

Para os autores, todos os modelos pedagógicos são mutáveis e a sala de aula, que também se transforma no tempo e no espaço, recebe influências (como políticas e econômicas) que afetam a práxis dos professores e, por conseguinte, o aprendizado dos alunos. Outrossim, todas as metodologias de aula possuem vantagens e limitações e devem sempre ser repensadas: não há verdades pedagógicas únicas. O que se critica é a estagnação em um único modelo, pois

implica numa visão demasiado simplista das capacidades dos aprendizes e das circunstâncias que lhes estimulam ou provocam o desenvolvimento. É perniciosa, porque a tentativa de emprestar vigência às regras nos conduz a acentuar algumas qualificações, em detrimento de uma formação humanitária mais geral. Além disso, a idéia é prejudicial à aprendizagem, na medida em que leva a ignorar as complexas condições físicas, históricas e motivacionais que exercem influência sobre a evolução intelectual do aprendiz (LABURÚ, ARRUDA, NARDI; 2003, p. 252).

Quando os estudantes são envolvidos em uma diversidade de metodologias de aula, podendo discutir conceitos físicos de diferentes formas, têm sua aprendizagem científica prestigiada (LEMKE, 1990). Ao contrário, em modelos de aula nos quais os alunos memorizam conceitos, leis e equações, sem de fato estabelecerem relações entre estes conhecimentos e com seu cotidiano, o objetivo principal acaba sendo apenas a aprovação na disciplina ou o treino para outros tipos de avaliações, como vestibulares (LIBÂNEO, 2002; BONADIMAN; NONENMACHER; 2007; MOREIRA, 2018). Nessas condições, geralmente

a participação do aluno é pouco solicitada, e quando o professor faz uma pergunta, ele próprio imediatamente a responde. É possível que entre os professores que se utilizam desses procedimentos de ensino haja alguns que levem os alunos a aprender os conceitos de forma mais sólida, que saibam lidar de forma autônoma com os conceitos. Mas não é o caso da maioria (LIBÂNEO, 2002, p. 5).

Nas aulas que seguem tal enquadramento, os conhecimentos prévios dos alunos, suas histórias de vida, seus contextos culturais e suas expectativas estão em segundo plano. Além disso, não há estímulo à independência, à consciência política, à cultura e outros aspectos sociais. Ainda, o desenvolvimento intelectual amplo dos estudantes acaba sendo prejudicado (LABURÚ; ARRUDA; NARDI, 2003). Aprender Física vai além da memorização de conceitos (ROBILOTTA, 1988; LEMKE, 1990; ROSA; ROSA, 2007; BALLESTERO; ARRUDA; PASSOS, 2018), é preciso saber usar esses conhecimentos em diferentes contextos e criar relações de significados entre eles: 
A student may know the definitions of "electron", "element", and "orbital", but that does not mean he or she could use those words together in a sentence correctly, or say how their meanings relate to each other. To do so, requires additional knowledge: knowledge of how these words aroused in talking science ${ }^{3}$ (LEMKE, 1990, p. 12).

Para que os alunos possam desenvolver a consciência dos contextos conceituais em suas aulas, a atuação do professor é imprescindível. Nessa via de mão dupla professor-alunos, o primeiro tem o papel de guia, propondo desafios e proporcionando situações, nas quais coincidam os objetivos da aula e os motivos dos alunos. Os estudantes, por sua vez, são aqueles que serão inspirados a serem protagonistas de seus processos de aprendizagem (HAYDT, 2011; LIBÂNEO, 2002). Apesar das dificuldades intrínsecas a esse processo, nas escolhas metodológicas é importante considerar as subjetividades dos estudantes, seus conhecimentos prévios, suas motivações e interesses, suas dificuldades e facilidades, suas preferências, entre outros aspectos, a fim de evitar um planejamento que seja divergente da realidade (CUNHA, 1995; LABURÚ; ARRUDA; NARDI, 2003; HAYDT, 2011). Nesse sentido, o conhecimento sobre História, Filosofia, Sociologia e Epistemologia da Ciência, além da percepção que o professor possui sobre Ciência são importantes elementos para sua postura pedagógica (CUNHA, 1995; LIBÂNEO, 2002; NARDI; CASTIBLANCO, 2014; DAMASIO; RODRIGUES, 2018). Somando-se a isso, tais compreensões, presentes nas escolhas metodológicas, podem evitar confusões que geralmente ocorrem, no imaginário de estudantes, entre aulas de Física e aulas de Matemática.

É indispensável que os professores reflitam sobre o conteúdo a ser abordado, a metodologia da qual lançarão mão e os motivos pelos quais ensinarão seu público alvo (NARDI; CASTIBLANCO, 2014). Ainda, é relevante preponderar as subjetividades da turma, uma vez que "as etapas e experiências particulares de cada um são influenciadas, no processo de desenvolvimento, devido às diferenças individuais" (LABURÚ; ARRUDA; NARDI, 2003). Além disso, Nardi e Castiblanco (2014) salientam a relevância da habilidade de decisão sobre quais conhecimentos físicos selecionar, uma vez que não é possível abordar todos os conteúdos. Portanto, é substancial que as aulas abranjam mais do que memorização sem um aprofundamento que propicie a formação de relações significativas ${ }^{4}$ entre conceitos contextualizados na Ciência e no cotidiano dos alunos.

Nardi e Castiblanco (2014) reforçam que em aulas de Física sejam utilizados conhecimentos que vão além do escopo da Física e que os alunos sejam levados a tecer críticas re-

\footnotetext{
${ }^{3}$ Um estudante pode saber a definição de "elétron", "elemento" e "orbital", mas isso não significa que ele ou ela poderia usar corretamente essas palavras juntas em uma frase, ou dizer como seus significados se relacionam um ao outro. Para fazer isso são necessários conhecimentos adicionais: conhecimentos de como estas palavras surgiram no ato de falar ciência. (LEMKE, 1990, p. 12, tradução nossa).

${ }^{4}$ Compreende-se por relações significativas, as que propiciam vínculos inteligíveis entre os conceitos físicos, considerando conhecimentos prévios dos estudantes (ARRUDA et al., 2004), a relação entre estes conceitos e o mundo (BONADIMAN; NONENMACHER, 2007), além de particularidades cognitivas, afetivas, sociais e culturais dos mesmos (LABURÚ; ARRUDA; NARDI, 2003).
} 
flexivas sobre suas realidades. Porém, surge a dúvida sobre como fazer isso. A dificuldade de responder à essa pergunta surge da ideia de que essa é uma atividade dos professores das ciências humanas e sociais (NARDI; CASTIBLANCO, 2014) e da carência de conhecimentos sobre Epistemologia das Ciências (BRONOWSKI,1979). Soma-se a isso que, no planejamento das aulas de Física não há regras, modelos prontos e automáticos, "receitas de bolo". Ainda, outra reflexão se faz importante: o que significa aprender Física? Lemke (1990) diz que aprender uma Ciência possui significado próprio: "Learning science means learning to talk science. It also means learning to use this specialized conceptual language in reading and writing, in reasoning and problem solving, and in guiding practical action in the laboratory and in daily life" ${ }^{\prime 5}$ (p. 1).

Aprender uma Ciência, falar Física, significa se apropriar dessa linguagem específica e seus significados. Significa estar apto a utilizar esta linguagem em diferentes contextos (BALLESTERO; ARRUDA; PASSOS, 2018). Desse modo, é importante que o professor esteja preparado para fazer escolhas em relação aos objetivos de aula, metodologias e recursos didáticos (NARDI; CASTIBLANCO, 2014).

Lemke (1990) compara o aprendizado de Ciência ao de outras linguagens: inserindo o estudante no contexto linguístico específico para que dialogue com sujeitos que já se apropriaram daquela linguagem. Na sala de aula é possível fazer isso com o professor e entre os próprios estudantes (LEMKE, 1990; BALLESTERO; ARRUDA; PASSOS, 2018). É sugerido que os estudantes se envolvam em escrita e leitura, que trabalhem o raciocínio lógico e se empenhem também na resolução de problemas, principalmente que envolvam o laboratório e as experiências do cotidiano (LEMKE, 1990). O trabalho com exercícios de cunho numérico tem seu papel nas aulas de Física, porém não é o único tipo de atividade possível. Além disso, seu ensino não deve ser repetitivo e focado na memorização de técnicas de resolução de problemas. Não bastará aprender as técnicas algébricas, é necessário discutir Física, falar Física de forma contextualizada. Ou seja, para o autor, a Ciência e seu ensino são processos sociais. Sendo assim, para proporcionar aos alunos a apropriação dessa linguagem, eles precisam aprender a fazer Ciência, a falar Ciência. Tendo isso em mente, são elencadas algumas atividades: observação, descrição, comparação, classificação, análise, discussão, formação de hipóteses, teorização, questionamento, desafios, argumentação, confecção de experimentos, julgamento, avaliação, tomada de decisão, conclusões, generalização, desenvolvimento de relatórios, escrita, leitura, etc.

Para aulas de cunho científico, Lemke (1990) entende que há dois tipos de padrões: o temático e o organizacional. O padrão temático é composto pelas relações semânticas que os alunos fazem entre cada conceito. O padrão organizacional é a forma como se desenvolve o diálogo entre os próprios alunos e entre eles e o professor. Além disso, há o padrão de diálogo

\footnotetext{
${ }^{5}$ Aprender ciência significa aprender a falar ciência. Também significa aprender a usar essa linguagem conceitual especializada em leitura e escrita, em questionamentos e resolução de problemas, e no desenvolvimento de ações práticas no laboratório e na vida cotidiana (p. 1, tradução nossa).
} 
triádico, composto por três etapas básicas: pergunta do professor, resposta de alunos e avaliação do professor. Nesse tipo de diálogo o professor mantém os movimentos comunicacionais sob seu controle. É entendido que esse tipo de padrão limita os alunos. Segundo Damásio e Rodrigues (2018), este tipo de atitude está associado a uma visão de Física que busca aproximações com verdades irrefutáveis, que pede certezas, não debates e questionamentos.

Nesse sentido, como destaca Moreira e Borges (2006, p. 159) é "preciso melhorar nossa compreensão sobre o que ocorre na sala de aula, ou seja, como professor e alunos conferem estabilidade ao seu contexto de ação, e como essa busca de estabilidade acaba por legitimar obstáculos a práticas de ensino mais inovadoras" e, neste caso, como o que ocorre na sala de aula no âmbito da díade forma $x$ conteúdo pode influenciar na formação de sentidos de aula de Física dos alunos.

\section{Noções de Análise de Discurso}

A teoria da AD francesa teve em Michel Pêcheux um de seus idealizadores e no Brasil foi muito difundida por Eni Orlandi. Este referencial compreende o conceito de discurso como sendo a língua em funcionamento propiciando sentidos entre sujeitos: "O discurso é assim a palavra em movimento, prática de linguagem" (ORLANDI, 2003, p. 15). Além disso, a ideologia é o mecanismo imaginário de formação de sentidos: condicionador da interação do sujeito com o mundo por meio da linguagem (BRANDÃO, 2002; ORLANDI, 2003). Nesse sentido, parte-se da prerrogativa da inexistência da ideologia como falsificação do meio (BRANDÃO, 2002). A ideologia passa a funcionar nos discursos por meio do processo de assujeitamento, ou seja, Orlandi (2017) expende que os indivíduos empíricos são interpelados pelas ideologias dos discursos com os quais têm contato e se tornam sujeitos históricos. Assim, passam a ocupar, inconscientemente, sua posição em determinado grupo discursivo colocando em questão o conceito de lugar e posição. Dessa forma, creem serem donos de suas próprias ideologias. Esses grupos, posicionados em formações ideológicas específicas, dialogam uns com os outros seja por confrontos, alianças ou relações de dominação que se expressam pelo discurso. Uma vez que o discurso é a materialidade da ideologia na língua, todo discurso está imbricado em uma formação ideológica (BRANDÃO, 2002; ORLANDI, 2003).

Neste processo é importante compreender que nenhum discurso é autônomo (ORLANDI, 2003). Isto quer dizer que, estando circunscrito em um contexto social, político e histórico específico, todo discurso é influenciado por outros discursos, dizeres anteriores: o interdiscurso, que faz parte das condições de produção, isto é, os sentidos produzidos estão sempre em função de condições de produção imediatas e amplas. Entre as imediatas, se considera quem fala, a quem fala, por qual motivo fala, em que lugar fala, de que forma fala etc. Em sentido lato, por exemplo, é considerada a situação política do país, a história de vida dos sujeitos envolvidos, a formação específica de cada professor, entre outros fatores.

A formação discursiva, por sua vez, dita o que deve ou não ser dito, preservando discursos padrões, sempre na busca de encontrar uma linha limítrofe para seu domínio discursivo 
(ORLANDI, 2017). Nesse contexto, há a importância de se compreender o significado do movimento de paráfrase, pelo qual, de maneiras diferentes e inconscientes, se replica sempre ditos anteriores. É um princípio que funciona como um conjunto de regras que condicionam como o sujeito se relaciona com o mundo por intermédio de seu arsenal ideológico: é o dito na base do dizível. Por outro lado, é pela polissemia que sentidos previamente estabelecidos são transformados (BRANDÃO, 2002).

Neste seguimento, à medida que os sujeitos não têm consciência de que reproduzem discursos anteriores, é função do analista descortinar os discursos, compreendê-los. Em sua tarefa, dá voz ao silêncio significante dos discursos, isto é, o dito no não dito; busca compreender seus sentidos e rastrear sua ideologia. Assim, o analista leva em conta o que já está fixo, o interdiscurso, e o que está em transformação, o intradiscurso.

Ainda, quando se trata do discurso, não há como não se levar em conta o fenômeno da formação imaginária:

a imagem que o sujeito faz dele mesmo, a imagem que ele faz de seu interlocutor, a imagem que ele faz do objeto do discurso. Assim como também se tem a imagem que $o$ interlocutor tem de si mesmo, de quem lhe fala, e do objeto de discurso. [...] em relação a este imaginário o que conta é a projeção da posição social do discurso. Desse modo, não é do operário que estamos falando, por exemplo, mas da imagem que nossa sociedade faz do operário. Ou do pai, ou do professor, ou do presidente etc. (ORLANDI, 2017, p. 18).

Assim, o imaginário também articula os dizeres, denunciando seu teor ideológico, bem como os diferentes aspectos das condições de produção. Tendo isso em conta, uma vez que o discurso é afetado pelo imaginário, o locutor pode se valer do mecanismo de antecipação, que é a capacidade de se colocar na posição de seu interlocutor e, assim, manipular seu discurso. Ademais, ainda em relação aos mecanismos discursivos, Orlandi (2017) discorre sobre as relações de sentidos, pelas quais todo discurso está relacionado a outros que também estão significando.

Dessa forma, o analista busca ir além da interpretação, compreendendo o discurso não só no que é dito, mas também nos não ditos, tendo em mente que a língua não é transparente e imutável; que o sujeito carrega seu discurso com a força que sua posição representa na sociedade: se fala da posição de patrão, de funcionário, de pai, de filho, de professor, de aluno etc.

Levando isso em consideração, ao estudar um discurso, é importante considerar o contexto histórico social que o influencia e o propicia. Logo, isso significa considerar o discurso como acontecimento em função de sua condição de produção.

Diante das ponderações até aqui realizadas cabe discorrer sobre o significado do discurso científico para Lemke (1990) e o discurso que se busca trazer à tona nesta pesquisa. Para Lemke (1990) aprender ciências significa se apropriar do discurso científico, no que diz respeito a aprender como determinados termos estão relacionados entre si e com o contexto na 
produção de significados específicos. Ou seja, o conhecimento científico está ancorado em uma estrutura particular, em características específicas indissociáveis do próprio conhecimento científico (leis, teorias, conceitos, princípios científicos, etc.). “A Ciência não requer apenas palavras com significados específicos, mas sim uma linguagem própria capaz de tornar possível o seu aprendizado e o seu desenvolvimento" (MASSI; QUEIROZ, 2011, p. 36). Dessa forma, o que Lemke (1990) faz é descrever algumas características, ou, segundo o próprio autor, preferências gramaticais envolvidas na linguagem científica, tais como o uso da voz passiva e dos verbos de ligação (ser, estar, ter, representar) ao invés dos verbos de ação.

Já na teoria da $\mathrm{AD}$, pode-se perceber outras características, como a abertura à interpretação que sugere um caminho de leitura no sentido de condução do leitor (ORLANDI, 1997), a construção de sentidos a partir da localização e apoio em condições de produção (ALMEIDA, 2004). Nesse sentido, busca-se compreender o movimento de interpretações dos sujeitos (nesta pesquisa os estudantes) procurando expor seus efeitos de sentido possíveis a partir do que se intitula de gestos de interpretação.

\section{A pesquisa}

A pesquisa, de natureza qualitativa (LUDKE; ANDRÉ, 1986) foi realizada com estudantes do Ensino Médio de uma escola pública do interior do estado de São Paulo. Como a proposta foi investigar discursos de alunos sobre aulas de Física e suas relações com metodologias utilizadas pelos professores, após contato com a coordenadora pedagógica da unidade escolar, foi efetuado o convite a turmas de primeira e de terceiras séries do Ensino Médio durante seus períodos letivos (manhã e tarde).

Para a escolha das seriações foi considerado o tempo de experiência com aula de Física que ambas as séries possuíam. Essa escolha foi feita baseada nos referenciais teóricos e metodológicos dessa pesquisa. Uma vez que os alunos da primeira série têm menos tempo de exposição às aulas de Física em comparação às outras séries do Ensino Médio, se mostraram um grupo de referência fértil para a escuta de sentidos de aula de Física. Por outro lado, os alunos da terceira série do Ensino Médio já passaram por um processo mais longo de assujeitamento (BRANDÃO, 2002; ORLANDI, 2003) - nos termos da AD - em relação à primeira série. Em relação a esses alunos, seus sentidos foram influenciados por suas experiências em quase três anos de aulas de Física. Nesse período de tempo maior, já tiveram também contato com professores habilitados ou não em Física e também considerando a particularidade da escola: única escola que oferecia, na época da pesquisa Ensino Médio público na cidade (sem considerar a Escola Técnica), um único professor formado e efetivado em Física, uso pouco frequente do laboratório de Física, grande quantidade de professores substitutos formados em outras disciplinas lecionando Física e presença marcante de estagiários. Essas foram as condições de produção consideradas para efeitos de seleção das seriações.

Do total de 44 estudantes que manifestaram interesse e se inscreveram para participar da pesquisa, somente oito (8) participaram efetivamente. Utilizando os contatos de celular 
fornecidos, foram criados grupos de mensagens de texto por meio de um aplicativo. Dessa forma, foi possível dialogar com os interessados e, de acordo com suas disponibilidades, foram organizados três encontros para a constituição de dados que se deu pelo método de grupos focais (GATTI, 2005). Na metodologia de grupos focais, voluntários são reunidos com a finalidade de se envolverem em debates sobre um ou mais temas relacionados às suas experiências pessoais e/ou sociais. Uma característica que diferencia este método de entrevista coletiva $^{6}$ é o fato de os participantes não fornecerem respostas diretamente ao moderador do grupo, mas discutirem entre si.

Os grupos focais, que duraram aproximadamente uma hora e meia cada, aconteceram em uma sala de projetos de ensino, de uma universidade da mesma cidade ${ }^{7}$, em dois diferentes finais de semana, durante o período da tarde. Dos três encontros realizados, dois foram com alunos de primeira série e um com alunos de terceira série, de acordo com a disponibilidade à participação na pesquisa.

Tabela 1: Grupos focais organizados, nomes fictícios dos participantes, séries e turmas das quais faziam parte na escola, além do período de estudo.

\begin{tabular}{|c|c|c|c|}
\hline Grupo & Discente & Série e turma & Período \\
\hline \multirow{2}{*}{ Grupo focal 1} & Aine & $1^{\mathrm{a}}$ série $\mathrm{H}$ & \multirow{2}{*}{ Manhã } \\
\hline & Diana & $1^{\mathrm{a}}$ série $\mathrm{H}$ & \\
\hline \multirow{3}{*}{ Grupo focal 2} & Athena & $3^{\mathrm{a}}$ série $\mathrm{W}$ & \multirow{3}{*}{ Manhã } \\
\hline & Osíris & $3^{\mathrm{a}}$ série $\mathrm{G}$ & \\
\hline & Brigite & $3^{\mathrm{a}}$ série $\mathrm{G}$ & \\
\hline \multirow{3}{*}{ Grupo focal 3} & Dionísio & $1^{\mathrm{a}}$ série $\mathrm{S}$ & \multirow{3}{*}{ Tarde } \\
\hline & Selene & $1^{\mathrm{a}}$ série $\mathrm{S}$ & \\
\hline & Íris & $1^{\mathrm{a}}$ série $\mathrm{S}$ & \\
\hline
\end{tabular}

\footnotetext{
${ }^{6} \mathrm{O}$ instrumento de constituição de dados foi validado por docente da Universidade responsável pelas disciplinas Pesquisa em Educação Científica I, II e III, que ocorrem durante três semestres, nas quais são desenvolvidas as atividades de apresentação das pesquisas desenvolvidas nos Trabalhos de Conclusão de Curso. Ainda, a validação também ocorreu por meio de um grupo focal piloto com estudantes do primeiro ano, do primeiro semestre de um Curso de Licenciatura em Física, uma vez que estes eram recém egressos do Ensino Médio e suas respostas poderiam ser consideradas muito próximas dos estudantes da seriação do Ensino Médio. Esse piloto foi filmado e transcrito sendo analisado posteriormente e verificado com intuito de avaliar o instrumento. Os resultados da análise deste grupo focal piloto foram, posteriormente, submetidos a um evento científico da área por meio de um trabalho, sendo aprovado e apresentado em forma de comunicação oral, bem como publicado na forma de artigo completo em periódico da área. Assim sendo, este instrumento de constituição de dados também foi validado por um evento científico e pareceristas da área que avaliaram o trabalho. A constituição de dados para a presente análise foi então realizada após todos os momentos supracitados.

${ }^{7}$ A escolha do lugar pautou-se pelo fato da pesquisa ter ocorrido no âmbito do desenvolvimento do Trabalho de Conclusão de Curso do autor e que este tinha acesso a espaços da Universidade considerados adequados para a realização dos grupos focais, mas também por considerar um lugar fora do ambiente escolar, conforme pressupostos que se pautam em princípios da técnica de Grupos Focais (GATTI, 2005). Considerou-se que é necessário, nos encontros, fornecer um espaço e atmosfera que sejam convidativos à exposição de ideias, debates, discussões e argumentações. Assim sendo, buscou-se trazer os alunos para um lugar diferente que pudesse ser mais convidativo à participação ativa nas atividades a serem desenvolvidas. Somando-se a isso, buscou-se selecionar um lugar onde não haveria interrupções e fosse confortável aos alunos.
} 
A função de moderador dos grupos focais foi exercida pelo primeiro autor deste trabalho e sua atuação seguiu os pressupostos apresentados por Gatti (2005), sobretudo o princípio da não-diretividade. Por esse pressuposto é entendido que o moderador não deve fazer intervenções afirmativas ou negativas, emitir opiniões pessoais ou conclusões: "O que ele não deve é se posicionar, fechar a questão, fazer sínteses, propor ideias, inquirir diretamente" (p. 9). A atuação do moderador deve ser a de guiar a discussão de maneira fluida entre os participantes, dentro do assunto da pesquisa, sempre tendo em mente que se está promovendo um momento de discussão para o grupo e não uma entrevista coletiva.

Para os três grupos focais foi pensado um roteiro de atividades que fossem incentivadores de discussão, além de um roteiro com tópicos de perguntas. Os encontros ocorreram iniciando com uma apresentação pessoal do pesquisador, além de uma breve explicação sobre os objetivos da reunião e da pesquisa. Em seguida, foi apresentado, por meio de um computador portátil, um vídeo ${ }^{8}$ do grupo de humor "Porta dos Fundos". Essa apresentação teve como objetivo proporcionar um ambiente descontraído e já propiciar um início de conversa, já que vídeo aborda uma aula que envolve exercícios numéricos. Outra atividade proposta levou os estudantes a escreverem comentários sobre suas aulas de Física em folhas de papel entregues a cada um. Essas folhas foram trocadas entre os participantes, que discutiram se concordavam ou não com o que liam. Os autores da escrita também justificaram o que escreveram e puderam argumentar com a pessoa que leu seu enunciado. Também foram entregues pequenos cartões com frases de opiniões sobre aula de Física para que os estudantes as categorizasse de acordo com seus níveis de concordância com as frases. Foi requerido que justificassem a categorização realizada. Alguns exemplos de frases foram: Física é Matemática aplicada; $O$ bom professor consegue passar o máximo de conteúdo possível; Em aula de Física deve haver bastante conta; Em aula de Física tem que haver associação com a vida cotidiana; Física é necessária para o vestibular; As aulas de Física não permitem muito os debates e discussões, entre outras. Todas as propostas de dinâmicas foram baseadas em sugestões de Gatti (2005) e tiveram o objetivo de oportunizar debates direcionados aos tópicos do seguinte roteiro:

- Falem sobre suas aulas (não somente de Física) do Ensino Médio.

- Falem sobre as aulas (não somente de Física) que mais te chamaram a atenção.

- O que vocês pensavam sobre aula de Física antes de terem essa disciplina?

- Falem sobre as suas aulas de Física.

- Falem sobre aulas de Física que chamaram sua atenção. Por que essas aulas chamaram sua atenção?

- Falem sobre seus professores de Física.

- Comentem sobre o que vocês gostam das aulas de Física.

\footnotetext{
${ }^{8}<$ https://www.youtube.com/watch?v=2vzwOeY9YUY>
} 
- Comentem sobre o que vocês não gostam das aulas de Física.

- O que vocês acham fundamental que haja em aula de Física?

- Que tipos de atividades vocês acham que não são possíveis de serem desenvolvidas em aulas de Física?

- De acordo com as aulas que vocês tiveram até agora, o que é Física, nas suas opiniões?

É sublinhado que nem sempre foi necessário enunciar todas as perguntas do roteiro porque os próprios estudantes abordavam os tópicos nos debates desenvolvidos durante as atividades propostas. Além disso, surgiram questões que não estavam previstas que foram expressivas para a investigação. Em relação a isso, Gatti (2005) comenta que é imprescindível que o moderador tenha sensibilidade aos movimentos discursivos durante um grupo focal para que possa perceber, de maneira fluída e oportuna, questões férteis para discussão.

Em relação aos professores ${ }^{9}$ que estavam lecionando a disciplina de Física no período de desenvolvimento da pesquisa tem-se: Aine e Diana tinham aula de Física com a professora Artemísia (que também recebe nome fictício), docente licenciada em Biologia e em Química $^{10}$. Uma mesma estagiária de Licenciatura em Física lecionava para Osíris e Brigite, enquanto outro estagiário era o professor de Athena. Dionísio, Selene e Íris, por sua vez, também tinham aulas de Física ministradas por uma estagiária da mesma disciplina.

Os encontros foram registrados em áudio e transcritos para posterior análise, que foi balizada pela teoria da AD francesa. Além disso, foi apresentado o termo de consentimento livre e esclarecido em duas vias por estudante, os quais deveriam ser assinados pelo aluno, por um responsável e pelo pesquisador.

\section{Análise dos discursos}

Pela teoria de AD francesa apresentada por Orlandi (2003, 2017), o processo analítico é dividido em três etapas. Antes da primeira etapa o analista tem contato com o corpus bruto ou objeto empírico; como diz Henry (1997 apud MONTEIRO, 2004), que "tal objeto não pode se destacar, através do jogo de um questionamento aleatório, da natureza que progressivamente o delimitaria tornando visíveis suas características (p. 44).

\footnotetext{
${ }^{9}$ Embora um dos professores não fosse formado em Física e os outros fossem estagiários de regência do Curso de Licenciatura em Física no momento em que a pesquisa foi realizada, parte-se do princípio de que os alunos tiveram contato com mais de um professor que lecionou a disciplina de Física desde o primeiro ano até o terceiro, uma vez que se trata de uma escola pública com muitas licenças e professores substitutos, sendo apenas um efetivo na escola e formado em Física, e que acaba não assumindo todas as turmas da escola na disciplina de Física.

${ }^{10} \mathrm{Na}$ escola estadual na qual os voluntários cursam o Ensino Médio há apenas um professor concursado em Física e, por isso, a presença de professores de outras disciplinas lecionando Física é muito comum. Ainda, como existe uma universidade no mesmo município, a presença de estagiários é muito comum.
} 
A primeira etapa, chamada de de-superficialização, consiste no analista trabalhar com a superfície linguística do texto, descrevendo suas condições de produção. Desse processo, o analista passa do discurso textual ao objeto discursivo. Na segunda etapa, o analista lida com o objeto discursivo e o relaciona com outras formações discursivas, buscando desfazer os efeitos de ilusão da autonomia do enunciador. $\mathrm{O}$ analista indica que o que está sendo dito em um trecho sob análise também é dito de outras formas por outros sujeitos por meio da paráfrase. A terceira etapa é a análise da discursividade. O analista chega à formação ideológica do discurso, sendo possível identificar o funcionamento de sentidos, pois "entre o objeto para o processo discursivo, passamos ao mesmo tempo do delineamento das formações discursivas para a sua relação com a ideologia, o que nos permite compreender como se constituem os sentidos desse dizer" (ORLANDI, 2003, p. 67).

Tais princípios nortearam a análise, na qual o corpus bruto foi composto por todas as transcrições dos três grupos focais. Já o corpus de análise se constituiu de recortes das transcrições, as unidades de sentido. A escuta dos discursos permitiu compreender os possíveis sentidos sobre aula de Física dos discursos dos alunos, de forma que foram "ouvidos" em função de uma importante condição de produção: as metodologias de aula. Dessa forma, as unidades de sentido foram selecionadas em função de abordar o "como" as aulas de Física eram desenvolvidas, ou seja, em função de aspectos metodológicos da aula que surgiram nos encontros dos grupos focais.

É desejado ressaltar que o imaginário articula sentidos mobilizados por relações de força das posições sociais de todos os sujeitos. Portanto, uma vez que os alunos foram informados, mesmo que brevemente, sobre os objetivos da pesquisa e que sabiam que estavam em um contexto de investigação, seus discursos durante os encontros podem ter sido influenciados, incorrendo no surgimento de mecanismos de antecipação.

De forma a possibilitar a leitura das unidades de sentido, são trazidos, a seguir, os códigos utilizados nas transcrições.

- [Frases entre colchetes]: indicações relevantes para a compreensão das falas transcritas. Exemplos: [Em voz alta], [Breve pausa], [Estudante interrompe a fala do colega].

- Três pontos: indicam a prolongação na pronúncia de alguma fala ou momento de pausa para possível reflexão sobre o que dizer a seguir. Exemplo: “É...”, "Hum...", "Então...".

- Três pontos dentro de colchetes [...]: indicam trechos da transcrição omitidos na presente análise.

• "Frases entre aspas": indicam coloquialismo. Exemplos: "pra", "pro cê ver", "tá ligado?".

A seguir é apresentada uma unidade de sentido na qual as alunas Aine e Diana falam sobre suas aulas de Física.

Moderador: E vocês também falam bastante na aula dela [professora]? Vocês disseram que ela [a professora] é bastante falante. 
Aine: Assim, na aula dela, eu não costumo, porque eu tenho dificuldade em Física e por isso na aula dela não converso tanto.

Diana: Então, ela fala, fala, fala, fala, fala e não pára, entendeu? Não tem como, mesmo se a sala estiver quieta, ela mesma já confessou isso. Ela fala demais.

Aine: "Uhum" [concordando com Aine].

Moderador: E vocês não falam muito com a professora nas aulas em discussões em Física entre vocês?

Diana: Não.

Aine: Debate não. Conversar não. Ela só passa matéria e passa umas contas na lousa, umas contas, "né”, só isso.

Diana: E se falar que não "tá” entendendo, aí... é pior ainda!

Moderador: Por quê?

Diana: Não "tá" entendendo?! [Imitando a professora em voz alta].

Aine e Diana são estudantes da primeira série do Ensino Médio e têm aula de Física com Artemísia, que apesar de estar exercendo a função de professora de Física, é licenciada em Biologia e em Química. O moderador as interroga sobre a existência de metodologias de aula mais dialogadas. Aine diz que não conversa muito nas aulas de Física porque tem dificuldade nessa disciplina. Isso pode significar a não apropriação dessa linguagem conceitual (o falar Física). Assim, a aluna também está dizendo que, se tivesse maior conhecimento e prática no discurso da Física, se envolveria com mais frequência nessas aulas. O seu falar nas aulas pode ser direcionado para o sentido de se envolver nas aulas segundo o que é apresentado por Lemke (1990), que entende que a apropriação da linguagem conceitual científica propicia maior envolvimento nas aulas e vice-versa. Essa interpretação coincide com o que é apresentado por Arruda et al. (2004) que explica que quando os estudantes possuem relações significativas com o objeto de estudo, podem atuar mais ativamente.

Logo após, Diana afirma que a professora é quem domina as falas e que não há muita abertura para que os alunos participem. De fato, mesmo que inconscientemente, muitas vezes os professores utilizam um padrão organizacional que os permite controlar as relações discursivas na sala de aula (LEMKE, 1990). Ainda, de acordo com o mesmo autor, existe uma concepção de aula enraizada no inconsciente dos professores. São aulas de Física autoritárias e que não permitem que os jovens se apropriem da linguagem científica, o que lhes admitiria uma participação mais ativa no processo de aprendizagem.

O moderador reformula sua pergunta e questiona se há debates e discussões nas aulas. Diana responde prontamente que "não" e descreve uma aula na qual o agente principal é o professor e sua metodologia se limita à apresentação de conteúdos e exercícios no quadro. Esse discurso perpassa por um imaginário relacionado a modelos de aula que limitam as aulas de Física a resoluções de exercícios em que a habilidade matemática é a todo momento requerida (CARVALHO JÚNIOR, 2002; DAMASIO; RODRIGUES, 2018), e também dos dias de 
hoje, que enfatizam principalmente o acúmulo de conteúdos (TSAI, 2002). Ballestero, Arruda e Passos (2018) afirmam que não são as definições que irão determinar o aprendizado de conceitos, leis e teorias físicas, mas sim suas relações com o mundo, com a natureza e com o cotidiano dos jovens.

Pereira et al. (2007), citando Perrenoud (1999), entendem que é importante "estimular o diálogo entre o espaço escolar e o mundo" (p. 5). Isso significa propiciar uma relação entre o mundo da vida, a realidade dos alunos e os conteúdos da Física escolar. O diálogo entre essas duas esferas de conhecimento passa por escolhas metodológicas fundamentadas na reflexão sobre a realidade dos estudantes (HAYDT, 2011). No trecho a seguir, Aine chama atenção para seu desejo de uma maior variedade metodológica:

Aine: Tipo, mostrar, sei lá, ir em um laboratório, mostrar como que, exemplo, a consistência dos outros planetas, como que conseguiram chegar à Lua. "Ah”, sei lá! Coisas diferentes "pra” gente chamar atenção, sabe? Sair um pouco, assim, sei lá, ir em algum lugar. Não ficar sempre na sala de aula. Não sei, entendeu? Explicar mais pra gente mesmo. Ir lá, ver o céu, explicar "pra" gente, explicar as contas também, como surgiu as contas de Física, como... entendeu? Essas coisas, eu acho que seria mais legal.

Aine ressaltou a necessidade de uma pluralidade metodológica e cita aulas em ambientes diferentes da sala de aula, como a realização de experimentos em laboratório. Interessante comentar que, o laboratório didático da escola veio a ser reativado no ano de 2017 por estagiários e bolsistas do Programa Institucional de Bolsas de Iniciação à Docência (PIBID) de um Curso de Licenciatura em Física de uma universidade pública da mesma cidade. Esse discurso também é marcado pela importância de um viés histórico nas aulas. A aluna exemplifica o caso da história de como o ser humano chegou à Lua e como as equações físicas chegaram a ser como são hoje. Damasio e Rodrigues (2018) concordam com essa perspectiva quando indicam que a Física faz parte de um panorama de desencadeamento cultural, político e histórico.

A aluna também reconhece a importância de problemas quantitativos e, além disso, concebe a necessidade de "explicar as contas também, como surgiu as contas de Física". Há um não dito em seu enunciado, de que pouco adianta ter apenas a manipulação algébrica se não houver a compreensão do que as equações significam na Física. É feito um destaque sobre a importância dos processos da Física, não somente os conhecimentos como produtos, já que, “[...] no ensino de cada disciplina científica, esse desenvolvimento não está somente a serviço dessa determinada ciência ou das ciências, mas sim promovendo uma competência geral de representação e comunicação" (BRASIL, 2002, p. 24).

A importância do pluralismo metodológico também é enfatizada por Athena que, ao falar do motivo de não gostar muito das operações algébricas, diz que seria interessante saber como os cientistas as desenvolveram: 
Athena: Então, é... "pra" mim, a parte de "conta" [...] é meio chato. Eu gosto mais de saber como foi o pensamento todo do... do... no caso, Newton, o que ele pensava quando ele "tava" fazendo as contas e... [...]

Moderador: Entendi. Como que... aqui você falou que gosta da parte que mais... que fala sobre como o cientista pensava.

Athena: Sim. Na hora de desenvolver a Ciência dele.

Moderador: Isso acontece aqui na sua aula de Física?

Athena: Não, não acontece. Aqui a gente, no caso, tá aprendendo mais é... o... Como fala? O... campo magnético, só aprende sobre o campo magnético, não como foi desenvolvido a teoria em si.

O discurso da aluna destaca o desejo por um viés histórico associado às aulas de Física. Esse discurso pode se filiar à concepção de que o pluralismo metodológico enriquece as aulas, como de fato indicam Laburú, Arruda e Nardi (2003). Ao mesmo tempo, mostra uma necessidade de compreensão da natureza da Ciência.

É plausível aproveitar a contribuição da História, da Filosofia e da Epistemologia da Física (CUNHA, 1995; LIBÂNEO, 2002; NARDI; CASTIBLANCO, 2014; DAMASIO; RODRIGUES, 2018). Além do mais, esses conhecimentos auxiliam a compreender a contribuição de outras áreas do conhecimento para as aulas de Física (BRONOWSKI, 1979; NARDI; CASTIBLANCO, 2014). Nessas condições se oportuniza uma aula que expressa preocupações com a formação para a cidadania e considera a Física como uma herança social historicamente localizada (BONADIMAN; NONENMACHER, 2007). Apesar de o discurso de Athena articular sentidos que valorizam a importância desses elementos, a aluna indica que em suas aulas não ocorre essa abordagem.

A mesma estudante diz que há aulas práticas que auxiliam no entendimento das equações. Pelo que foi analisado, o sentido de aula de Física que aparenta estar funcionando é o que compreende que deve haver a prática da linguagem conceitual da Física por diferentes metodologias. Isso pois, mesmo que a estudante indique ter dificuldades, também denota que por meio das aulas práticas passa a ter mais facilidade na compreensão dos conteúdos. Dessa forma, é assumido que o aprendizado dos alunos pode ser beneficiado por metodologias diversificadas (LEMKE, 1990; LABURÚ; ARRUDA; NARDI, 2003; NARDI; CASTIBLAN$\mathrm{CO}, 2014)$.

No dito de outra aluna:

Aine: [...] Eu gosto também de coisas diferentes que saem do... um pouco de copiar, responder, copiar e responder.

Ainda, na voz de outros participantes: 
Íris: "Ah”, eu gosto de Biologia e de Física.

Moderador: Entendi. O quê que nessas aulas chamou sua atenção?

Íris: Tem bastante dinâmica, sabe?

Moderador: Na aula de Biologia? E na Física?

Íris: De Física, "ah", a gente vai "pra" outra sala, explica direitinho, slide, é mais interessante do que aula normal no quadro.

Selene: E ela faz experiência; assim, fez experiência com vela, com figuras geométricas, com secador de cabelo. Que tipo, coloca a vela acesa, aí atrás tem... [interrompida por Dionísio].

Dionísio: É "pra” explicar a aerodinâmica do avião.

Íris: É!

Dionísio: Você pega um negócio retangular e pega o secador, vai apagar a vela?

Selene: Não vai apagar a vela!

Dionísio: Não vai apagar a vela porque a forma é muito grande.

Selene: É! Não vai apagar a vela.

Dionísio: Aí o retangular meio que dá uma turbulência. Ele se espalha ao redor tudo.

Íris: Se espalha pro lado.

Dionísio: $O$ do triângulo ele contorna.

Íris: É, é isso.

Nessa unidade, os alunos conversam sobre metodologias utilizadas pela professora estagiária. Comentam que vão para outros espaços, que a professora utiliza slides, faz boas explicações e proporciona atividades práticas. De acordo com os alunos, essas aulas são mais atrativas. Outrossim, a importância da relação dialógica professor-aluno pode ser rastreada na unidade a seguir:

Moderador: Falem de aulas que mais chamam a atenção de vocês no Ensino Médio.

Aine: Eu. O que eu gosto? Eu gosto mais de Biologia.

Moderador: Como são essas aulas, de Biologia, que mais chamam a atenção?

Aine: “Ah", é porque a gente aprende bastante coisa. É que em Bio... A última aula que a gente teve de Biologia eu tirei bastante dúvida minha, a professora explica bem, sobre insulina, sobre todas as coisas, até lembrei agora. A gente, é... fala sobre bastante coisa. A professora, assim, conversa bastante com a gente também. Ela explica, e tem... eu tenho mais vontade de aprender, então pra mim é melhor.

$[\ldots]$

Moderador: E você, Diana, que aulas que te chamam atenção?

Diana: Sociologia e Língua Portuguesa.

Moderador: Por quê? 
Diana: [...] por causa do que a Aine falou, ela sabe desenvolver... ter um desenvolvimento melhor com a sala, "pra” falar "com nós" e é a melhor professora na minha opinião.

Ao falar sobre aulas que mais se destacaram, Aine se referiu à disciplina de Biologia. Destaca-se que, a mesma professora que leciona Biologia (Artemísia) também leciona Física. Aine explica que gosta das aulas de Biologia, pois consegue tirar dúvidas, a professora explica bem e há maior dialogicidade: por isso consegue atuar mais ativamente. Ao mesmo tempo, traz um exemplo de um assunto que foi tratado nessas aulas. Ela explica que há maior interação com a professora e que, por isso, consegue participar mais que em outras aulas nas quais isso não ocorre.

Fazendo referência à dialogicidade presente nas aulas, Diana explica seu interesse em Sociologia e em Língua Portuguesa. Interessante frisar que essas são aulas consideradas da área das Humanas. Esse discurso pode estar apontando para uma condição de produção que sofre influências de uma cultura na qual, em aulas de disciplinas Exatas, esses tipos de metodologias são menos prestigiados e aceitos.

No discurso dos alunos:

Athena: Eu tenho mais facilidade nas [aulas] de humanas em geral. Agora, nas matérias de exatas, aí eu acho que não vai. Biologia eu acho que vai um pouco, mas vai. Agora, Matemática, Física, Química, já tenho mais... acho que questão não tipo... da matéria em si, mas da forma que o professor " tá" ensinando.

Moderador: $O$ que acontece nas disciplinas da área que você chamou de humanas que faz com que você tenha mais facilidade?

Athena: O método que o professor ensina, que é mais conversação mesmo, pedindo a opinião dos outros, vendo o ponto de vista de cada um, dependendo da matéria.

Moderador: E vocês concordam? [Se dirigindo aos outros participantes] $O$ que vocês acham disso? Com o que ela [Athena] acabou de dizer.

Brigite: Concordo.

[...]

Moderador: [...] Tem diferença pra você [Brigite] entre as disciplinas de humanas e as de exatas? Igual ela [Athena] fez essa... [Interrompido por Brigite].

Brigite: Total!

Moderador: Qual é? Qual é essa diferenciação "pra” você?

Brigite: Nas disciplinas de humanas o método costuma ser mais oral, sabe? Os professores falam mais, se comunicam mais. Em exatas não muito.

Moderador: Nessas aulas de humanas vocês conversam mais com o professor também? Vocês se comunicam com ele?

Brigite: Conversa! Acaba tendo também leitura, discussões, textos e a gente acaba participando mais. 
Nessa etapa da discussão é denotado por Athena que há maior facilidade, de sua parte, nas disciplinas comumente chamadas de Humanas. Não se argumenta fazendo referência a dificuldades ou facilidades com conteúdos de cada disciplina, mas sim às metodologias adotadas. Comparando as disciplinas de Humanas e Exatas, é apontado por Brigite que, nas primeiras há discussões, leituras e, consequentemente, maior participação dos alunos. Ao mesmo tempo, o não dito presente no discurso é que, em aulas de Ciências consideradas Exatas, as metodologias não permitem maior interação ou mesmo que não como diversificar em aulas de exatas.

Esse discurso sobre aula de Física vem se estendendo na historicidade do discurso: como Carvalho Júnior (2002) ressaltou, esse tipo de aula que considera pouco as subjetividades dos alunos predomina desde o século passado. A Física, nesses discursos, é entendida como um corpo de conhecimento irrefutável e livre das subjetividades dos alunos (DAMASIO; RODRIGUES, 2018). Consequentemente, as aulas acabam não comportando metodologias que lançam mão, por exemplo, de debates: a presença de elementos sociais, culturais e subjetivos fica limitada. Na unidade a seguir os alunos indicaram maior interesse em aulas nas quais podem se envolver em discussões e debates:

Moderador: [...] Eu vou ler as frases e então vocês falam o que concordaram ou não e a gente debate. [Seleciona um cartão e lê em voz alta] Em questão de tipos de atividades que podem ser feitas em aulas, na aula de Física não pode faltar... [em tom de quem sugere que a frase seja completada]. [...]

Aine: Eu acho que debates. Seria legal.

Moderador: Por quê?

Aine: "Pra" gente aprender. "Pra" professo... "pra"... "pra” professora, na hora que estiver ali, ver o que a gente pensa e saber se é certo ou não e ensinar. Entendeu? Eu acho, não poderia... Pelo menos uma vez por mês, pelo menos uma vez por mês, ter um debate em sala de aula.

Moderador: Por que só uma vez por mês?

Aine: Porque eu acho que é suficiente.

Moderador: Então, ter debate sempre em aula de Física, você acha que não é adequado?

Aine: Não. Mas eu acho que uma vez, por mês é o suficiente.

Diana: Eu acho que é adequado.

Moderador: Por quê?

Diana: Ah, porque desenvolve melhor.

Aine: Mas e o que você realmente precisa aprender? "As contas" e as matérias? Não vai atrapalhar? Não ia atrapalhar; ter sempre?

Diana: Debate não é "pra" tirar as dúvidas?

Aine: Mas não vai te ensinar "contas”, o que você realmente precisa. 
Esse debate se iniciou em uma atividade na qual as alunas categorizaram frases de acordo com concordância ou não concordância. Algumas das frases precisavam ser completadas, como a que foi lida pelo moderador. Aine destaca as atividades de debates pois, segundo ela, facilitam o aprendizado. Lemke (1990) e Cunha (1995) apontam que os alunos sentem-se mais contemplados quando há espaço para suas subjetividades. Isso se dá apesar de possuírem um imaginário, muitas vezes inconsciente, que dita que as aulas de Ciências devem ser impessoais e autoritárias. Ainda existe certa resistência por parte de professores e alunos em legitimar aulas de Física que utilizam metodologias que discordam desse conjunto de crenças: os alunos podem até mesmo pensar que o que está sendo ensinado não é uma Ciência genuína (LEMKE, 1990).

Existe então uma contradição na qual os alunos se interessam por aulas com metodologias mais diversificadas, mas as deslegitimam quando se trata, por exemplo, de aula de Física. Pelo enunciado de Aine, aulas com metodologias diversificadas envolvendo debates não devem ser muito frequentes, pois atrapalhariam o suposto real interesse dessas aulas, as famosas contas.

Foi percebido que, mesmo quando as aulas são mais dialogadas, ainda pode existir um padrão organizacional de controle e isso também é influenciado pelos sentidos que se tem de disciplinas científicas (LEMKE, 1990):

Moderador: Como que são essas aulas, que vocês não estudam e aprendem? Como que são essas aulas?

Diana: “Ah”, as aulas que a professora fala, que ela desenvolve melhor, que lê, explica... Aine: Explica melhor, fazem perguntas, elas fazem perguntas e "nós responde" e ai ela fala "Não, não é isso; é isso, parabéns!" [Reproduzindo falas da professora]. Entendeu?

Diana: Incentiva mais, a aprender.

As alunas entendem que nas aulas em que há mais diálogo há maior aprendizado. Todavia, o tipo de diálogo predominante nas aulas é o do padrão triádico. Basicamente o professor pergunta, o(s) estudante(s) responde(m) e o professor emite uma avaliação sobre a resposta. Dessa forma, são articulados sentidos que reforçam a ideia de respostas certas ou erradas, da existência de uma objetividade a ser alcançada. É uma aula de uma Ciência dita Exata, na qual nem todas as ideias são parabenizadas, que é deslocada da realidade e das subjetividades. Nesse tipo de aula, não há o que se debater de/sobre Física: há que se oferecer informações cristalizadas. Laburú, Arruda e Nardi (2003) contrapõem, dizendo que aulas que não priorizam respostas certas podem ser mais significativas aos alunos.

A unidade de sentido a seguir versa sobre os debates em aulas de Física:

Moderador: Vocês conseguem dar a opinião de vocês sobre conteúdos da Física? Tipo, você concorda ou não concorda com aquilo? Isso acontece na aula de vocês? 
$[\ldots]$

Íris: Na maioria das vezes, porque ela [professora estagiária] pergunta o quê que você acha. Ela não fala "É isso!", ela faz perguntas do tipo "O que você acha?". Mesmo que você não saiba, vocêfala o que você acha que é aquilo.

Íris diz que consegue emitir opiniões sobre os conteúdos de Física durante as aulas. Segundo ela, a professora não aborda os conhecimentos científicos de maneira autoritária, mas que consiera o conhecimento prévio dos alunos. A discussão continuou nesse mesmo tema quando Íris leu uma das frases sobre aula de Física que foram apresentadas aos alunos para que argumentassem sobre:

Íris: [Lendo] Não seria possível emitir minhas próprias opiniões sobre os conceitos e conteúdos que são abordados em Física. [Traz opinião após a leitura] Eu discordo. [...] Porque eu posso dar minha opinião! Mesmo eu "tando" errada, "tando" certa.

Moderador: E você faz isso nas suas aulas de Física?

Íris: Sim.

Moderador: Você pode falar de uma situação que isso aconteceu?

Íris: Igual o do avião. Ela [a professora] perguntou como que a gente achava que ele subia. Daí a gente falou e ela explicou de um jeito totalmente diferente do que a gente achava que era.

Moderador: O que vocês acham sobre isso? Vocês acham que dá, "pra", na aula de Física, você emitir sua opinião?

Selene: Porque aí, você vendo a opinião da outra pessoa, você pensa de um jeito diferente, tenta pensar como a pessoa e aí você aprende mais.

Iris: Verdade. Você tenta entender também aquela pessoa, mesmo que você não concorda.

Durante a atividade de proposta de categorização e argumentação sobre frases a respeito de aulas de Física, Íris discorda da frase que declara não ser possível emitir opiniões sobre conteúdos científicos. A aluna diz que, por meio das opiniões dos outros colegas também é possível aprender, pois há um esforço em lidar com outras ideias sobre o mesmo assunto. Quando se pensa sobre o desenvolvimento da Ciência, o National Research Council (2007) apresenta que ele é possibilitado tanto pelo corpo de conhecimentos científicos quanto pelos processos de produção dos mesmos. Certamente o embate de ideias faz parte da aprendizagem científica (LEMKE, 1990; BALLESTERO; ARRUDA; PASSOS; 2018; DAMASIO; RODRIGUES, 2018). Este tipo de abordagem possibilita que os estudantes construam conhecimentos e se aproximem dos saberes científicos de forma mais ativa e significativa (LABURÚ; ARRUDA; NARDI, 2003; BONADIMAN; NONENMACHER, 2007).

Compreende-se, do discurso de Íris, que o padrão organizacional da professora estagiária não é do tipo triádico, já que outorga maior relevância para o processo de argumenta- 
ção. A própria aluna traz indícios de que, por este processo, seu aprendizado é valorizado. Nesse contexto, a argumentação, a discussão e a tomada de decisões são prestigiados.

Nessas aulas há a oportunidade de os estudantes aprenderem a falar Física: observam fenômenos, discutem, argumentam, criam hipóteses, confrontam ideias, etc. É valorizada a aprendizagem de uma linguagem que não é mais importante que a dos alunos, mas que oferece uma possibilidade de desenvolvimento de diferentes elementos em uma formação para a cidadania. Esse discurso contrasta com aquele de Aine e Diana quando discorreram sobre as metodologias empregadas em suas aulas: "Eles [os professores] não, não debatem mesmo. E eles não permitem discussões entre nós, entende? Ela [a professora] passa ali e você aprende aqui".

A seguir são apresentadas três unidades de sentidos nas quais são discutidas possibilidades metodológicas, por exemplo, com o uso de poemas, histórias em quadrinhos e filmes:

Moderador: [Seleciona outro cartão e lê em voz alta] Não é possível estudar Física por meio de histórias em quadrinhos, poesias, filmes, etc.

Aine: Porque tem coisa que "num"... "cê" vai aprender ali, mas "num" é verdade. É ficção e... não é verdade, aí você vai gravar aquilo na cabeça, ai "cê" chega lá e não tem nada a ver, entendeu? Eu acho que não é possível.

A aluna não legitima metodologias que lançam mão de certos tipos de texto, pois entende que seus conteúdos não possuem caráter de veracidade. Na próxima unidade, o mesmo assunto é trazido à tona:

Moderador: Athena, dá "pra" estudar Física por meio desses tipos de atividades? Histórias em quadrinhos, filmes, poesias... Se o professor levasse isso na aula de Física, o que você acharia?

Athena: Também pode ser vídeos, essas coisas também? Porque eu acho que dá sim, eu aprendi muita coisa vendo até mesmo filme, série, essas coisas.

Moderador: Você pode comentar alguns vídeos que você viu e que você aprendeu?

Athena: Vídeo que eu vi foi do Manual do Mundo.

Moderador: Manual do Mundo?

Athena: $E$.

Moderador: E você, Osíris, você acha que dá "pra” estudar Física com história em quadrinho, poesia, narrativa, textos jornalísticos, filmes, séries...

Osíris: Tem alguns que sim.

Moderador: Alguns conteúdos ou alguns... [Interrompido pelo participante]

Osíris: Tem alguns com aquela parte fictícia e tudo, mas tem alguns que sim. A Athena citou o Manual do Mundo. É por aí. 
Moderador: Entendi. E você? [Se referindo à Brigite] Você disse que não concorda com isso, né?

Brigite: É, que eu não concordo que não dê "pra” estudar.

Moderador: Por quê?

Brigite: Hum... porque, tipo... "Cara”, eu acho que, o filme, ou o quadrinho, ou a presença de qualquer coisa estranha é voltada passando a Física "pra” você, tipo, você não vai aprender Física lendo alguma coisa, em um artigo que está falando só sobre Língua Portuguesa, é claro. Mas se tiver alguma coisa sobre Física, tipo, um conceito de Física, você aprende com certeza.

Athena diz que já aprendeu com filmes e séries, mas usa a expressão "até mesmo". Ao escolher essa expressão, aparenta suscitar sentidos de que, geralmente, não é possível aprender Física com aqueles tipos de texto. Athena cita um canal de uma plataforma de vídeos online no qual são postados vídeos de curiosidades científicas, em geral no modelo de entretenimento. Osíris argumenta que o caráter fictício de poesias, filmes, histórias em quadrinhos são um empecilho, mas que outros meios, como os vídeos do canal citado por Athena, podem ser utilizados desde que abordem especificamente sobre conteúdos científicos. Nessa mesma linha de raciocínio, Brigite acredita que é possível utilizar os tipos de textos citados caso tratem especificamente de conteúdos físicos. Um dito da mesma participante indica que não se aprende Física por meio da leitura, a não ser que ela esteja conceituando conhecimentos científicos.

A ficção científica parece não ser muito bem aceita pelos alunos. De acordo com a aluna Aine, há elementos nesses recursos que não são dotados do que seria uma rigorosidade científica. Esse discurso traça um caminho a sentidos de que aulas científicas devem ser objetivas, distantes dos efeitos da cultura, do imaginário e da criatividade humana (BRONOWSKI, 1979; LEMKE, 1990). Diante disso, levanta-se o questionamento sobre o motivo da dificuldade em aceitar a contribuição de elementos da cultura a favor ou articulados as aulas de Física: "What is it, however, that is so abnormal about discussing science fiction in a science class? Why is it so rare that we hear references to TV, movies [...] in science class? Why

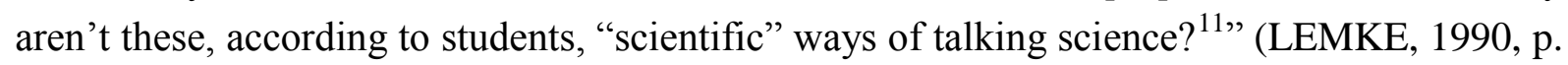
131).

De acordo com o autor existe essa dificuldade, pois há um conjunto de regras no inconsciente de alunos e professores acerca do que é o genuíno falar científico, do que é a genuína aula de Física. Essas normas refletem uma Física escolar que deve ser formal, cujo discurso é objetivo e evita referências à ficção e à fantasia, ao coloquialismo, à personificação de conceitos, à linguagem figurativa e metafórica, aos relatos narrativos e dramáticos.

\footnotetext{
${ }^{11}$ E qual é o motivo, todavia, pelo qual é tão anormal a discussão de ficção científica em uma aula de ciência? Por que é tão raro ouvirmos referências à TV, filmes [...] em aulas de ciência? E por que estes não são, segundo os alunos, modos científicos de falar ciência? (p.131, tradução nossa).
} 
Tais formações de sentidos sobre aula de Física nutrem as escolhas de metodologias de aula. Consequentemente, influenciam também os discursos dos estudantes, seja para pensarem na aula como uma disciplina autoritária e baseada em manipulações algébricas, seja para a perceberem como um espaço que promove a participação ativa, o embate de ideias e a construção coletiva do conhecimento de uma Física localizada histórica, social e culturalmente.

\section{Algumas considerações}

Neste artigo foi apresentada uma análise dos discursos de alunos do Ensino Médio sobre aulas de Física e suas possíveis relações com as metodologias de aulas. Os discursos suscitaram sentidos de uma aula de Física que se filia a metodologias que privilegiam o acúmulo de conteúdos, além de resoluções repetitivas de exercícios sem significados mais profundos aos alunos. Nessas condições, os objetivos dos alunos se concentram em alcançar a aprovação na disciplina. Ainda, não há o estímulo ao questionamento, ao debate, à argumentação e a Física acaba sendo entendida como uma verdade científica irrefutável. Também, há o imaginário de uma aula na qual o agente principal é o professor e as subjetividades dos estudantes não são consideradas, bem como o caráter social, histórico, político, cultural da própria Física.

Foi possível identificar discursos sobre uma aula de Física pautada em metodologias diversificadas que propiciam a participação mais ativa dos alunos na construção do conhecimento. Nesses casos, a atuação docente é do tipo mediadora e estimula a criatividade, a dialogicidade e os alunos são incitados à prática da argumentação. Consequentemente, os estudantes que têm aulas nessas condições acabaram demonstrando maior interesse pela Física. Isso porque são motivados por aulas que possuem uma gama maior de possibilidades metodológicas.

É defendido que as aulas de Física propiciem a prática de atitudes, habilidades e competências em uma formação para a cidadania, possibilitando que os alunos possam falar Física em diversificadas propostas metodológicas. Nessas condições, é feito o apontamento de atividades variadas como observação, descrição, comparação, classificação, análise, formação de hipóteses, teorização, questionamento, desafios, argumentação, experimentação, julgamento, avaliação, tomada de decisão, conclusões, generalização, escrita, leitura, entre outras.

Não se apregoa o fim de problemas em aulas de Física, tampouco o uso da lousa e do giz. Ao invés disso, é proposta uma reflexão a respeito da estagnação de metodologias nas quais os estudantes apenas copiam da lousa, escutam o professor e resolvem exercícios repetitivos sem significados conceituais mais profundos além do manuseio de equações. Em aulas desse tipo, resta aos alunos decorarem os conteúdos com objetivo de aprovações em avaliações somativas. Pode surgir a dúvida sobre que metodologias são ou não são bem vindas nas aulas de Física e é entendido que os conhecimentos de Epistemologia, História, Filosofia e 
Sociologia da Ciência podem auxiliar a compreender a contribuição de outras áreas do conhecimento para o ensino das Ciências.

É considerado que as aulas de Física são um espaço social. Dessa forma, é sugerida a articulação de um ensino que forneça aos jovens a oportunidade de aprenderem a falar Física possibilitando reflexões de valores e interesses sociais. Defende-se aulas que permitam a compreensão de que essa Ciência é tão inteligível como qualquer outra disciplina; que Física é uma construção social e está sujeita à falha e que não é um método para encontrar verdades irrevogáveis. Portanto, sendo propiciadas as condições de produção que levem em conta essas considerações, os discursos dos estudantes podem ser (re)construídos e (trans)formados de maneira que possam compreender a Física como um processo social, cultural, histórico acessível e uma aula que reflita esses princípios.

Diante do que foi apresentado é novamente reforçada a ideia de que não se pretende responsabilizar os professores por todas as problemáticas que envolvem o contexto das aulas de Física. A fim de nutrir novas discussões a partir deste artigo, é sublinhada a ideia de que as políticas públicas valorizem as escolas, a profissão docente e suas formações inicial e continuada. Outrossim, é incentivado que as instituições de ensino superior reflitam sobre a formação que estão oferecendo aos futuros educadores em Física. Apesar de todas as dificuldades envolvidas no âmbito escolar, como é dito por Cunha (1995, p.153): “O professor e o aluno não podem ser engolidos pelo ritual escolar. Precisam ser sujeitos conscientes, definidores deste ritual". Deste modo, é esperado que este artigo possa suscitar reflexões frutíferas sobre o ensino de Física e de Ciências, sobre professores, alunos e as aulas de Física.

\section{Referências}

ALMEIDA, M. J. P. M. Discursos da Ciência e da Escola: ideologia e leituras possíveis. Campinas: Mercado de Letras, 2004.

ARRUDA, S. M.; VILLANI, A.; UENO, M. H.; DIAS, V. S. Da aprendizagem significativa à aprendizagem satisfatória na educação em ciências. Caderno Brasileiro de Ensino de Física, Florianópolis, v. 21, n. 2, p. 194-223, 2004.

BALLESTERO, H. E.; ARRUDA, S. M.; PASSOS, M. M. A aprendizagem da linguagem física em um curso de introdução à Mecânica Clássica. Caderno Brasileiro de Ensino de Física, Florianópolis, v. 35, n. 1, p. 2-19. 2018.

BONADIMAN, H.; NONENMACHER, S E. B. O gostar e o aprender no ensino de Física: uma proposta metodológica. Caderno Brasileiro de Ensino de Física, Florianópolis, v. 24, n. 2, p. 194-223, 2007.

BRANDÃO, H. H. N. Introdução à Análise do Discurso. 1 ed. Campinas: Editora da Unicamp, 2002. 
BRASIL. Ministério da Educação. Secretaria da Educação Média e Tecnológica. Orientações Educacionais Complementares aos Parâmetros Curriculares Nacionais ( $\mathrm{PCN}+$ ). Brasília: MEC, 2002.

BRASIL. Lei de Diretrizes e Bases da Educação: Lei no 9.394/96 - 24 de dez. 1996. Estabelece as diretrizes e bases da educação nacional. Brasília, 1998.

BRONOWSKI, J. O homem e a ciência: ciência e valores humanos. São Paulo, Ed. da Universidade de São Paulo, 1979.

CARVALHO JÚNIOR, G. D. As concepções do ensino de Física e a construção da cidadania. Caderno Catarinense de Ensino de Física, v. 19, n. 1, p. 53-66, abr. 2002.

CUNHA, M. I. A relação professor-aluno. In: Repensando a Didática, Veiga, I. P. A. (org.). 10. ed. Campinas: Papirus, p. 145-158, 1995.

FEYERABEND, P. Contra o método. 3. ed. Rio de Janeiro: Francisco Alves, 1977.

FREIRE, J. C. A. A visão do aluno de Ensino Médio acerca da Física e suas relações com a Matemática-Tecnologia-Cotidiano. 2007. 21 f. Trabalho de Conclusão de Curso (Licenciatura em Física). Universidade Católica de Brasília, Brasília.

GATTI, B. A. Grupo focal na pesquisa em ciências sociais e humanas. Brasília: Liber Livro, 2005.

HAYDT, R. C. C. Curso de Didática Geral. 1. ed. São Paulo: Ática, 2011.

LABURÚ, C. E.; ARRUDA, S. M.; NARDI, R. Pluralismo metodológico no ensino de ciências. Ciência e Educação, v. 9, n. 2, p. 247-260, 2003.

LEMKE, J. L. Talking science: language, learning and values. Norwood, NJ: Ablex, 1990

LIBÂNEO, J. C. Didática: velhos e novos temas. Edição do autor. 2002. Disponível em: <http://professor.pucgoias.edu.br/SiteDocente/admin/arquivosUpload/5146/material/Did\%C3 \%A1tica\%20-\%20\%20Velhos\%20e\%20novos\%20temas.doc>. Acesso em: 20 fev. 2017.

MASSI, L.; QUEIROZ, S. L. Jogo discursivo na apropriação da linguagem científica por alunos científica por alunos e iniciação científica em química. Investigações em Ensino de Ciências, v. 16, n. 1, p. 35-57, 2011.

MOREIRA, A. M. Uma análise crítica do ensino de Física. Estudos avançados, v. 32, n. 94, p. 73-80, 2018.

MOREIRA, A. M.; BORGE, O. Por dentro de uma sala de aula de física. Educação e Pesquisa, v. 32, n. 1, p. 157-174, 2006. 
NARDI, R.; CASTIBLANCO, O. Didática da Física. São Paulo: Cultura Acadêmica Editora, 2014.

ORLANDI, E. P. As formas do silêncio: No movimento dos sentidos. Campinas: Editora da UNICAMP, 1997.

ORLANDI, E. P. Análise de Discurso: princípios e procedimentos. 5 ed. Campinas: Pontes Editores, 2003.

ORLANDI, E. P. Análise de discurso. In: ORLANDI, E. P.; LAGAZZI-RODRIGUES. S. (Orgs.) Introdução às ciências da linguagem - Discurso e textualidade. Campinas: Pontes Editores, 2017. p. 13-36.

PEREIRA, A. S.; COELHO, M. F. F.; SILVA, M. M.; COSTA, I. F.; RICARDO, E. C. Um estudo exploratório da concepção de alunos sobre Física no Ensino Médio. In: SIMPÓSIO NACIONAL DE ENSINO DE FÍSICA, XVII, 2007, São Luiz, MA. Anais... Disponível em: <http://www.sbf1.sbfisica.org.br/eventos/snef/xvii/sys/resumos/T0565-1.pdf>. Acesso em: 22 mar. 2017.

RICARDO, E. C; FREIRE, J. C. A. A concepção dos alunos sobre a física do ensino médio: um estudo exploratório. Revista Brasileira de Ensino de Física, v. 29, n. 2, p. 251-266, 2007.

ROBILOTTA, M. R. O cinza, o branco e o preto - da relevância da história da ciência no ensino da física. Caderno Brasileiro de Ensino de Física, v. 5, n. Especial, Florianópolis, p. 7-22, 1988.

ROSA, C. W.; ROSA, A. B. Ensino da Física: tendências e desafios na prática docente. Revista Iberoamericana de Educación, v. 42, n. 7, p. 1-12, 2007.

SILVA, P. O.; KRAJEWSKI, L. L.; LOPES, H. S.; NASCIMENTO, D. O. Os desafios no ensino e aprendizagem da Física no Ensino Médio. Revista Científica da Faculdade de Educação e Meio Ambiente, Ariquemes, v. 9, n. 2, p. 829-834, 2018.

TSAI, C. C. Nested epistemologies: Science teacher's beliefs of teaching, learning and Science. International Journal of Science Education, v. 24, n. 8, p. 771-783, 2002.

ZABALA, A. A prática educativa: como ensinar. Porto Alegre: Editora Artmed, 1998.

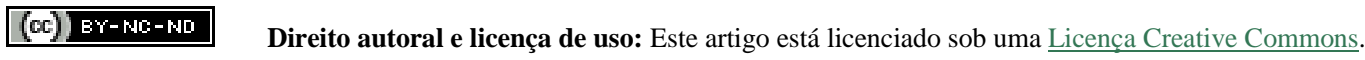

